\title{
FEES AND ENCROACHMENT ON PRIVATE PRACTICE
}

\section{To the Editors of THE BRITISH JOURNAL OF OPHTHALMOLOGY.}

DEAR SIRS,- - I write to congratulate those responsible for the Annotation-Fees-in your Journal of July, which gives timely support to the long-established custom of doctors engaged in private practice being free to name their own fees and modify them to meet their patients' circumstances. As there can be little doubt that the pre-eminence of British medicine is largely due to the freedom this custom gives to patient and doctor alike, I wish to draw attention to facts and figures which apparently have not been seen by the writer of the Annotation, who does not appear to have appreciated how the scope for private practice has been greatly curtailed.

Unfortunately, many of us are to blame for the present state of affairs, by the maintenance of an eighteenth-century taboo which has resulted in little consideration being given to the fact that there has been little, if any, decrease in the calls for gratuitous service, in spite of the increase in social services. In 1913, these cost the country $£ 63,000,000$; in $1939 £ 531,000,000$ and are now in the region of $£ 1,400,000,000$.

Nor was this the only encroachment on private practice, for in July, 1912, National Health Insurance came into operation and, owing to the conservative policy of the Government, medical benefits were restricted in favour of capital reserves which reached $£ 150,000,000$ in 1940 . They must be much greater now owing to the low incidence of sickness during the war and the fact that $2,000,000$ previously unoccupied people have been brought into industry. State funds are liable to be, and indeed have been, appropriated for purposes other than that for which they are collected, and the profession's high ethical code makes it particularly vulnerable to such a policy, for politicians are very sensitive to the claims of a majority, which is never likely to be obtained by the sick. A further blow to private practice was suffered from the extension of National Health Insurance to include those with incomes up to $£ 420$ per annum, and it must be remembered that there is no income limit for manual workers.

The most recent encroachment on private practice is the extended powers given to education authorities under the Education Act of 1944, which imposes on them the duty of making arrangments to secure the provision of free medical attention for pupils from the ages of 2 to 15 years, in any school or county college maintained by such authorities. The successful opposition of most of them to the B.M.A.'s recommendation of a 20 per cent. increase in the fees of part-time doctors in their employ, as a war-time measure, is significant, for "sparing justice feeds iniquity."

Fortunately, the public has been as slow to appreciate the 
changing circumstances as those to whom we have entrusted our material interests and, therefore, the full consequences have not yet been seriously felt, chiefly owing to the war-time increase in earnings from $£ 1,734,000,000$ in 1938 to $£ 2,930,000,000$, that is, approximately 70 per cent. The following figures show that the lower income groups have benefited most, and therefore, there is no justification for the doctor-patient-fee relationship to be discarded, at a time when the public has been able to save $£ 9,000,000,000$, of which $£ 3,500,000,000$ were "small savings," in spite of more being spent on beer, tobacco, clothing and entertainment.

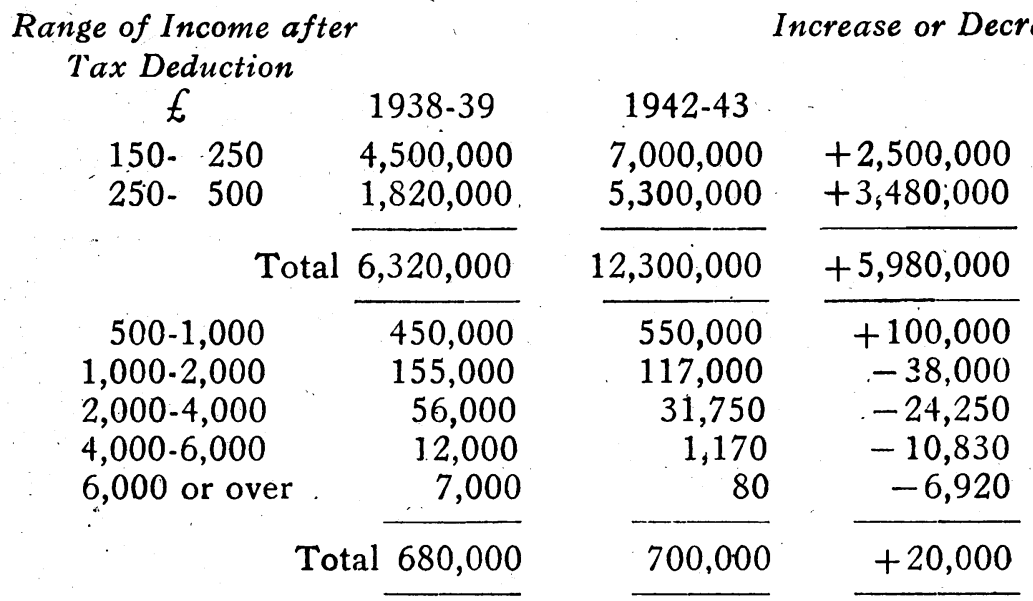

In view of these facts, one is left wondering what is the real aim of those who seem intent on undermining the spirit of independence which was such an estimable characteristic of the British people until a multiplicity of grandiose schemes were announced as being "free for all.".

Yours faithfully,

H. RICHARD BICKERTON.

LIVERPOOL,

July 20, 1945.

\section{HETEROPHHORIA AND NEUROSIS IN FLYING PERSONNEL}

To the Editors of The BRITISH Journal of Ophthalmology.

DEAR SIRS, - We have read with interest the above article which appeared in the Brit. Jl. Ophthal. of March, 1945, but feel that the 